Article

\title{
Structure and Formation Mechanism of China-ASEAN Tourism Cooperation
}

\author{
Jie Yin ${ }^{1}$, Yahua $B i^{2, *(\mathbb{D})}$ and Yingchao $\mathrm{Ji}^{1}$ \\ 1 College of Tourism, Huaqiao University, Quanzhou 362021, China; yinjie@hqu.edu.cn (J.Y.); \\ JJuly717@163.com (Y.J.) \\ 2 Department of Tourism and Convention, Pusan National University, Busan 46241, Korea \\ * Correspondence: yahuabi@pusan.ac.kr; Tel.: +82-10-9584-0831
}

Received: 16 June 2020; Accepted: 2 July 2020; Published: 6 July 2020

\begin{abstract}
Tourism cooperation is an essential element for tourism development in China-ASEAN countries and has made a significant economic contribution to destinations. This study investigates the structure of tourism cooperation in China-ASEAN relations and identifies a set of factors that affect tourism cooperation from a network perspective. By employing social network analysis, the results indicate that the scale of cooperation is small, and the efficiency is not high, although the restrictions on cooperation between countries are reduced. The findings also indicate that differences in the political system, security, population density, and language can promote tourism cooperation, while differences in governance, income, and consumption level impede tourism cooperation. The research results may assist China-ASEAN countries to formulate tourism strategies suitable for international cooperation and national differences.
\end{abstract}

Keywords: tourism cooperation; China-ASEAN; cooperation structure; driving factors; regional tourism

\section{Introduction}

With the in-depth development of tourism, competition in the tourism market is becoming increasingly fierce [1]. Under the complex and competitive atmosphere, tourism cooperation, as an important element for tourism destinations to obtain competitiveness [2], has become a vital consideration for practitioners and scholars. Morrison et al. [3] pinpointed that various countries utilize partnerships to develop tourism, indicating that tourism cooperation becomes an organization's preference [4,5]. As such, tourism cooperation is regarded as an important approach to promote the sustainable development of tourism [6]. Researchers have examined the issues surrounding tourism cooperation in various industries [7-9], such as sport industries [10] and forest, mining, and tourism industries [11]. In the context of tourism, scholars mentioned that tourism cooperation can be explored through the cooperation network [5].

The cooperation network is identified as a coherent pattern of interactions and interconnections between organizations, as opposed to such organizations being isolated in the system $[5,12]$. In particular, through the cooperation network, organizations collaborate to obtain mutual benefits and win-win results $[9,13]$. The network, as a concept, has been widely adopted in international tourism $[9,14]$.

However, although cooperation projects related to international tourism have been launched globally $[15,16]$, international tourism cooperation networks of these projects have been ignored to a certain extent [3]. It is unclear how international tourism cooperation projects interact, especially from a perspective of the network structure. Concerning these successful tourism cooperation projects, it is necessary to interpret the characteristics of tourism cooperation and the factors that influence tourism cooperation. 
The Association of Southeast Asian Nations (ASEAN, including Brunei, Cambodia, Indonesia, Laos, Malaysia, Myanmar, the Philippines, Singapore, Thailand, and Vietnam), a well-known cooperation project, is experiencing a boom in both foreign and domestic tourism with tourism becoming one of its foremost industries [17]. Tourism is one of the main priority sectors for ASEAN [18]. Furthermore, the ASEAN National Tourism Organizations (ASEAN NTOs) formulated a plan of action for ASEAN cooperation in tourism. The issues for the tourism cooperation of ASEAN have drawn increasing attention. Issues of tourism demand [19-21], tourism flows [22], cooperation trends and prospects [23], intergovernmental collaboration [24], supranationalist alliances [25] and the preconditions and policy framework [26] of tourism cooperation in ASEAN have been done in the past. Additionally, as an important partner and neighboring country of ASEAN, since 2012, China has become the source of the largest outbound tourism globally [27] and one of the world's major recipients of tourists [28] with the number of inbound visitors expanding enormously. China has conducted cooperation with ASEAN in different fields, such as trade [29,30], security [31], economic [32] education [33] and tourism $[18,22,34-36]$.

What is more, for ASEAN countries, the most important goal is to maintain close and beneficial cooperation with each other [19], especially tourism cooperation that brings huge economic benefits. Beritelli [2] suggested that it is effective to identify the codependent relationship between partners from the network perspective to induce cooperative behaviors. However, given the research on the tourism cooperation of ASEAN, relatively little research has explored how tourism cooperation is formed and what are the characteristics of tourism cooperation. Within this context, strengthening tourism cooperation with China can achieve close cooperation in China-ASEAN relations. Therefore, this research complements previous research on China-ASEAN by exploring the structure of their tourism cooperation with its characteristics and relationships, and investigating the driving factors and formation mechanism while deconstructing the tourism cooperation from the network perspective.

To accomplish it goals, this research adopts social network analysis (SNA) to examine tourism cooperation. First, this study elucidated the cooperation structure while exploring the essential characteristics of China-ASEAN tourism cooperation by taking overall characteristics and individual characteristics into account from 1998 to 2017 (The reason for choosing this period is that various events affect international tourism cooperation during this period. In 1967, ASEAN was formally established. ASEAN membership reached nine countries in 1997 and ten countries in 1999. In 2001, China joined the world trade organization. SARS broke out in 2003, the global financial crisis broke out in 2009, and the Belt and Road Initiative (BRI) was put forward in 2013. To comprehensively analyze the structure, characteristics and formation factors of China-ASEAN tourism cooperation, the years before and after the formation of the 10 countries as well as the years that affect tourism cooperation by international events were included in the research period). Second, this study explained the reasons that such a characteristic cooperative network is formed by investigating what the essential driving factors are affecting the tourism cooperation network (The driving factors affecting tourism cooperation networks would be explored by employing Quadratic Assignment Procedure (QAP) analysis, which was introduced in detail in the following context).

In summary, the China-ASEAN relations in the current study provide an excellent research context for understanding tourism cooperation. This study also provides two important contributions to the tourism literature: (1) This study shows the essential factors that affect tourism cooperation. In detail, differences in terms of income, governance, and consumption level have negative effects on cooperation networks presently, whereas differences in population density, security, and the political system promote cooperation networks. The findings enhance the comprehension of tourism cooperation in the China-ASEAN network. (2) This study clarifies the structure of tourism cooperation in China-ASEAN and provides valuable references for increasing tourism benefits and establishing new strategic plans. Overall, figuring out the structure and examining the influencing factors of tourism cooperation in China-ASEAN countries helps remove cooperation obstacles, optimize cooperation structure, and promote sustainable tourism cooperation among China-ASEAN countries. Therefore, 
the findings of this research will contribute to a deeper and more valuable understanding of international tourism cooperation.

\section{Literature Review}

\subsection{Tourism Cooperation Network}

Tourism cooperation enhances regional relations and drives regional economic development; as such, tourism cooperation is regarded as an effective way for the sustainable development of tourism $[5,37,38]$. Considering the vital role of tourism cooperation, past research has investigated tourism cooperation on travel behaviors [39], tourism establishments [5], and tourist movement patterns $[40,41]$.

Tourism development is accompanied by fierce competition [42]; therefore, scholars emphasized that the issues related to tourism cooperation need to be addressed [43-45]. Early research on tourism cooperation mainly focused on cooperation obstacles, opportunities, strategies, and methods [34,35,43,45,46]. Jamal and Getz [43] proposed the principles for urban tourism cooperation from a planning view. Cetinski and Weber [45] explored the possibility of establishing sound cooperation among the multinational tourism markets. Elliott [47] analyzed the measures on cooperative management among administrations. Bramwell and Angela [44] proposed a framework for tourism cooperation decision making.

Additionally, the advancements of transportation and globalization have promoted tourist flows, thus forming a diversified tourism phenomenon. Then, the network theory and network science approaches $[48,49]$ were introduced into tourism to reveal the complex tourism phenomenon. According to network theory and network science, a network describes organizations aligning together to form inter-organizational networks or a type of flexibly designed network structure [50]. In other words, the network refers to a special structure consisting of different actors or organizations and their connections with others. Chung et al. [51] employed the social network analysis approach to reveal that global tourism networks have become highly consolidated. Provenzano and Baggio [52] also found that Sicily has a complex destination structure through inbound tourism. Yi et al. [53] observed that the networks in village tourism committees in China are diffuse. Due to the advantages of revealing connections and structure, the network science approach has been widely employed in tourism cooperation.

The network has been adopted in various tourism studies [9]. Past studies have been interested in tourism destination cooperation [54], tourism enterprise cooperation [55], and tourism geography cooperation [56]. Tourists move on a worldwide scale currently and construct a heterogeneous and complicated network [57]. However, little research focuses on international tourism cooperation, indicating that international tourism cooperation networks are still a relatively neglected area [3]. To bridge the research gap, this study investigates cross-border tourism cooperation from the network perspective.

\subsection{Research Context: China-ASEAN}

Even though tourism cooperation in the China-ASEAN counties has become close and frequent, academic studies related to intergovernmental collaboration in tourism among China-ASEAN counties seemingly remain few in number [26]. Chirathivant [23] discussed the trends and prospects of ASEAN-India tourism cooperation. Chang, Khamkaew, Tansuchat and McAleer [20] applied a multivariate conditional volatility model to investigate the interdependence of international tourism demand and encouraged regional cooperation in tourism development among ASEAN member countries. In recent years, tourism cooperation among ASEAN countries has made some progress. For Thailand, the number of tourists to Thailand from ASEAN countries and Thailand's foreign exchange earnings saw an average growth rate of more than $10 \%$ [58]. 
Despite ASEAN countries having numerous opportunities for tourism cooperation, they still face various challenges [24,59]. Koh and Kwok [59] assessed the progress undertaken by the ASEAN establishment in terms of tourism development and evaluated the possible challenges of such intra-regional cooperation. To promote tourism cooperation, Wong, Mistilis and Dwyer [24] explored the factors that facilitated and hindered progress for tourism cooperation in ASEAN and identified that the lack of implementation of tourism integration has hindered the promotion of tourism cooperation. Then researchers explained the preconditions that gave rise to ASEAN tourism and the formulation of the policy framework [26]. Based on the promotion factors, obstacles, and prerequisites of tourism cooperation, the mechanism of ASEAN tourism collaboration [60] were displayed.

Given the lack of analysis of tourism cooperation from an empirical perspective, it is crucial to understand the tourism cooperation relationships between China-ASEAN counties. More importantly, China-ASEAN countries need to promote the sustainable growth of tourism [61]. Thus, this paper focuses on the tourism cooperation of China-ASEAN and intends to reveal the characteristics of tourism cooperation.

\subsection{Determinants of Tourism Cooperation in China-ASEAN and Hypothesis}

Even though the previous studies investigated certain issues on tourism cooperation of China-ASEAN, there seems to be a lack of experimental testing of the determinants of collaboration. Thus, this paper makes efforts to empirically examine the determinants of tourism cooperation. Concerning the factors affecting international tourism cooperation, Czernek [8] proposed some main issues, including exogenous factors (i.e., economic, income, political changes), endogenous factors (i.e., cost, level of tourism development, geographical distance, and political changes), and global factors (i.e., global environment). Wong, Mistilis and Dwyer [26] argued that political, social, and economic development alongside variations may be the preconditions for tourism cooperation of China-ASEAN. Curiosity is one of the main motivations of tourists [62], which means the difference between the source country of tourists and the destination country is an important reason for tourists to form international tourism activities. Additionally, the premise of cooperation is that partners can complement each other [32]. Based on the aforementioned discussion, we argue that the difference may be the basis of tourism cooperation. Therefore, according to the influencing factors of tourism cooperation, we aim to investigate and empirically test how these factors affect the tourism cooperation in China-ASEAN from the perspective of differences.

(1) Political system difference (PSD): Numerous studies have pointed out that political factors can influence the development of tourism [63-66]. For ASEAN countries, political factors have greatly affected the development of tourism [67-69]. The political system is the comprehensive embodiment of political factors and the cohesion of a country's political factors. Differences in the political system could lead to great differences in policies and development directions, which may make cooperation between the two countries difficult to occur. Based on the above analysis, the hypothesis was posited below:

Hypothesis 1. The difference in the political system negatively affects tourism cooperation in China-ASEAN.

(2) Governance difference (GD): Governance is a key concept in politics and public policy [70], which reflects the government's comprehensive measures on a series of issues including industry, society, and livelihood. For tourism, governance capacity is an important guarantee for tourism development [71,72]. If the governance of a country is high, there is a positive environmental benefit for its tourism industry. Therefore, we argue that the great difference in governance between the two countries may result in a huge difference in the environment for the tourism industry. The difference in the tourism industry development may restrict the complementary advantages of limiting tourism cooperation. Accordingly, the relationship between governance difference and tourism cooperation is postulated as follows: 
Hypothesis 2. The difference in governance negatively affects tourism cooperation in China-ASEAN.

(3) Income difference (ID): Tourism activities need the support of discretionary income [35]. Moreover, income represents a country's economic development level to some extent. As for international tourism activities, tourist flows are affected by numerous economic factors, such as price, income, and exchange rate [36,73-76]. In general, most countries may be reluctant to cooperate with countries with weak economies. Hence, in this situation, tourism cooperation between the two countries may be weak. If there is a big income difference between countries, tourist flows between them are difficult. Thus, we propose that:

Hypothesis 3. Income difference negatively affects tourism cooperation in China-ASEAN.

(4) Consumption level difference (CLD): In essence, tourism is a consumption activity, which is largely influenced by the consumption level of destination [77]. The higher the consumption level in the destination country is, the higher the cost for foreign tourists to travel in the country. However, the travel cost would affect the demand for travel [78]. Therefore, we claim that the difference in consumption level may restrict tourists' demand, which is negative for tourism cooperation. Based on the above discussion, it is hypothesized that:

Hypothesis 4. Consumption level difference negatively affects tourism cooperation in China-ASEAN.

(5) Security difference (SD): A safe destination environment is an important basis for tourists to travel to that destination [79]. Generally, tourists would not go to unsafe destinations. For tourism cooperation, crime rates are important problems that ASEAN countries currently face in the tourism industry [19]. Therefore, it is suggested that tourists travel to countries with low crime rates. This means that the greater the security difference, the more likely tourists travel, which leads to the following hypothesis:

Hypothesis 5. Security difference positively affects tourism cooperation in China-ASEAN.

(6) Population density difference (PDD): Anser et al. [80] observed that population density substantially decreased inbound tourism and international tourism receipts. Currie and Falconer [81] claimed that low population density benefits tourism development. High population density limits tourism demand. Therefore, tourists from a country with a higher density in the population are likely to travel abroad to hunt for a low-population-density country. Accordingly, we infer that:

Hypothesis 6. Population density difference positively affects tourism cooperation in China-ASEAN.

(7) Language difference (LD): Concerning the international tourism, language is treated as the cost for tourists [51] as languages are different among countries and regions. Thus, the difference in language is included in constraining factors for international tourism [82]. As for convenience, tourists would select the destination country speaking the same language. As such, the following hypothesis is proposed:

Hypothesis 7. Language difference negatively affects tourism cooperation in China-ASEAN.

\section{Research Design}

\subsection{Measurement for Tourism Cooperation}

Through the relationships between social networks, different connections can be understood, such as communication connections and network relationships [83]. In the 1960s, the gravity model was 
introduced $[84,85]$ and then was widely employed to measure the relations in the tourism cooperation network $[37,53]$. Moreover, various studies utilized the gravity approach to explore international tourism dynamics in the tourism network [51], which denotes that the model is well applied to interpret the cooperation network in the global tourism environment $[51,86]$. Hence, the current research selected the gravity model to explore tourism cooperation connections in China-ASEAN counties. Based on Equation (1) of the gravity model, tourism cooperation connections were examined.

$$
F_{i j}=\sqrt{T_{i} I_{i}} * \frac{\sqrt{T_{j} I_{j}}}{D_{i j} * D_{i j}}
$$

where $F_{i j}$ represents the tourism cooperation links between country $i$ and country $j ; T_{i}$ and $T_{j}$ are the number of tourists in country $i$ and country $j$, respectively; $I_{i}$ and $I_{j}$ are the tourism income of country $i$ and country $j$, respectively; and $D_{i j}$ is the geographical distance between country $i$ and country $j$.

However, spatial distance [51], time distance [87], and cultural distance [88], etc., can influence the intensity of tourism cooperation to a certain extent. The aspects that affect tourism cooperation make it necessary to modify the gravity model instead of using a single gravity model. Therefore, researchers recommend using a modified gravity model to interpret the tourism cooperation connection $[89,90]$. Additionally, tourism cooperation has strong economic characteristics, such as economic distance, affect tourism relations between countries [91]. In the tourism environment, tourism cooperation could be also influenced by the industrial development environment, such as local culture and service quality [16,92-94]. Based on the aforementioned discussion, the current research introduces economic distance and the industrial development environment to modify the gravity model (see Equation (2)).

$$
F_{i j}=K_{i j} * \sqrt{T_{i} I_{i}} * \frac{\sqrt{T_{j} I_{j}}}{G D_{i j} * E D_{i j}}
$$

where $F_{i j}$ refers to the tourism cooperation links between country $i$ and country $j$; $K_{i j}$ represents the industrial development environment, describing the tourism cooperative attraction coefficient of country $i$ and country $j . K_{i j}$ is acquired through Equation (3) [95]. Additionally, $G D_{i j}$ and $E D_{i j}$ represent the geographical distance and economic distance between country $i$ and country $j$, respectively.

$$
K_{i j}=\frac{S I_{i}}{S I_{i}+S I_{j}}
$$

where $S I_{i}$ and $S I_{j}$ are the ratios of employment in the service industry to the total employment for country $i$ and country $j$ (i.e., the proportion of employment of the service industry in total employment). By taking the economic distance measurement method [15], economic distance was investigated by Equation (4).

$$
E D_{i j}=\frac{\left(G D P P C_{i}-G D P P C_{j}\right)^{2}}{G D P_{i} * G D P_{j}}
$$

where $E D_{i j}$ is economic distance between country $i$ and country $j$; GDPPC $C_{i}$ and $G D P P C_{j}$ are the per capita GDP of country i and country $\mathrm{j}$, respectively; and GDP $i$ and GDPj are the GDPs of country $i$ and country $j$, respectively.

\subsection{Social Network Analysis}

Social network analysis interprets social cooperation through the network [96-98] and is applied in various tourism studies $[40,99,100]$. For example, Leung, Wang, Wu, Bai, Stahura and Xie [40] employed the social network to investigate tourist movement patterns. In the study of Luo and Zhong [100], communication characteristics of word-of-mouth in tourism interaction were explored by adopting the network analysis. The method is well developed to systematically study the social structure by measuring network density, centralization, betweenness, and structural holes [98]. Besides, 
the Quadratic Assignment Procedure (QAP) is commonly employed in the social network to investigate the influencing factors of the network [101,102].

Network density reflects the ratio between the actual link and the maximum number of links in the network [39]. A high density indicates a tight network connection.

Centralization contains the degree, betweenness, and closeness of centralization. When the centralization is close to 1 , the network is close to concentration [103].

Betweenness is mainly used to measure the ability of individuals in the network to act as "intermediaries" and "mediators", which represent the individual's "control ability" [104]. The high betweenness indicates the importance of master resources and information flow, and the lack of such betweenness can cause communication failure to other connections as well.

Structural holes are explored by effective size, efficiency, and constraints [105]. The effective size measures the control power of a node in the network. The larger the value, the stronger the control power of the node. Efficiency reflects the degree of influence of a node on other nodes in the network. The larger the value is, the stronger the influence. Constraints denote the degree of a node to utilize structural holes. The smaller the value, the higher the degree is.

QAP (Quadratic Assignment Procedure) regression analysis was employed to understand the factors influencing tourism cooperation. The QAP regression analysis can efficiently reduce multicollinearity issues [106,107]. The correlation coefficient can be obtained by the QAP regression analysis using permutation matrix data, and nonparametric tests were then operated on the matrices to discover major aspects that influence tourism cooperation.

\subsection{Data Collection}

Tourism cooperation in China-ASEAN countries aims to increase the number of tourists and tourism revenue. Hence, this study uses the number of international tourists and international tourism expenses (Equation (2)) to measure cooperative ties between countries. The proportion of the employment of the service industry in total employment (i.e., the proportion of employment of the service industry in total employment) was applied to calculate the industrial development environment [95].

Concerning the determinants of cooperation, if two countries have the same political system, there is no difference in the polity between the two countries, and the political system difference (PSD) is 0 ; otherwise, it is 1 . Six indicators ("voice and accountability, political stability and absence of violence/terrorism, government effectiveness, regulatory quality, rule of law, and control of corruption") [108] were regarded as the worldwide governance indices. The current research applies the average of the above six indicators to test the governance, which has been well utilized in previous studies (e.g., $[109,110])$. For language difference (LD), when two countries use the same official language, the value is set to 1 ; otherwise, set the value is set to 0 . The income of tourists is measured by gross national income (GNI) and income difference is measured by the gap of GNI of two countries. The consumption level difference (CLD) is measured by the gap in per capita consumption of two countries. Security difference (SD) between the two countries is computed based on the difference in intentional homicide rates obtained from the source of the United Nations Office on Drugs and Crime's International Homicide Statistics (UNODC). Population density difference (PDD) is measured by the gap in population density between the two countries.

To test the indictors' differences among countries including GD, ID, CLD, SD, and PDD, we measured the subtraction of the indictor among China-ASEAN countries year by year and used the average of these subtractions as an index for identifying the indictor's difference. In detail, if the subtraction of the indictor of the two countries is less than the index, we then argue that there is no difference in the indictor between the two countries and set it as 0 . If it is greater than the index, we suggest that there is a difference by setting it as 1 .

The data (number of international tourists (T), international tourism income (I), GDP, GDP per capita, service industry employment, total employment, GNI, population density, per capita 
consumption and governance) calculated in the current research is derived from the World Bank (https: //data.worldbank.org). The official language data and spatial distance data (the spatial distance from one capital to another is regarded as the geographical distance between the two countries in China-ASEAN) use the database generated by CEPII (http://www.cepii.fr/CEPII/en/bdd_modele/bdd.asp). In this paper, the data range is from 1998 to 2017.

\section{Results}

\subsection{The Structure of Tourism Cooperation in China-ASEAN}

\subsubsection{Characteristics of the Tourism Cooperation Network}

Based on the revised gravity model, we calculated the tourism cooperation links among China-ASEAN countries from 1998 to 2017. These cooperation links among countries are employed to construct tourism cooperation networks among China-ASEAN countries with the help of social network analysis. In this study, we set the average value of the tourism cooperation links from 1998 to 2017 as the breakpoint value. Then, we set the relationship value as 1 if the value of the tourism cooperation relationship between the two countries was higher than the average value; otherwise, it was set to 0 . We construct the tourism cooperation relationship matrix, and then show the visual analysis for the tourism cooperation network based on the closeness of each country for five stages, including 1998, 2002, 2007, 2012, and 2017 (see Figure 1). The closeness of a country means the extent to which it is not controlled by other countries in a cooperative network. Generally, the higher the value of the closeness is, the freer of the country is. As for calculating the number of the relationship value in these five charts, the numbers of cooperation ties in China-ASEAN countries are 39 in 1998, 38 in 2002, 43 in 2007, 50 in 2012 and 56 in 2017, indicating that the linkages of tourism cooperation networks are more intensified over time as revealed by the number of cooperation relations that have increased stably. According to Figure 1, we find that Singapore and Brunei are largely on the periphery of the tourism cooperation network, with few links to other countries.

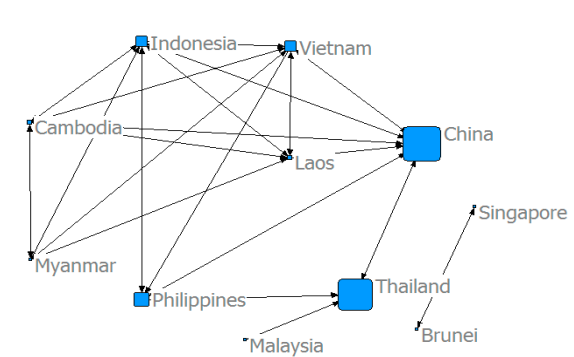

(a) 1998

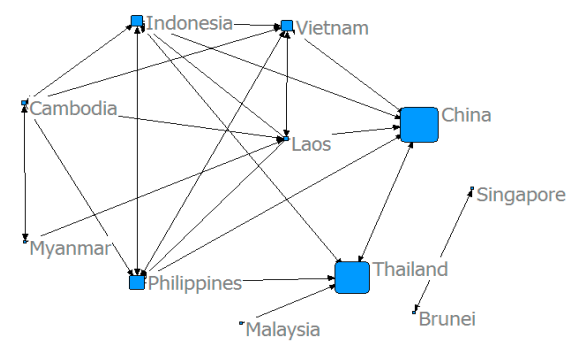

(b) 2002

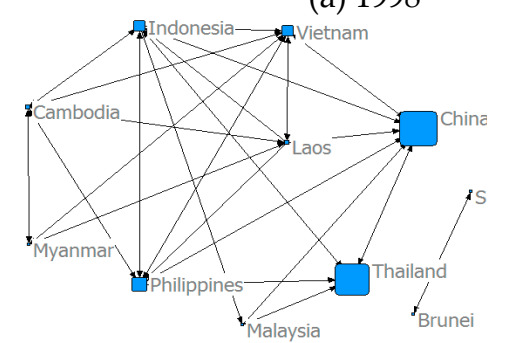

(c) 2007

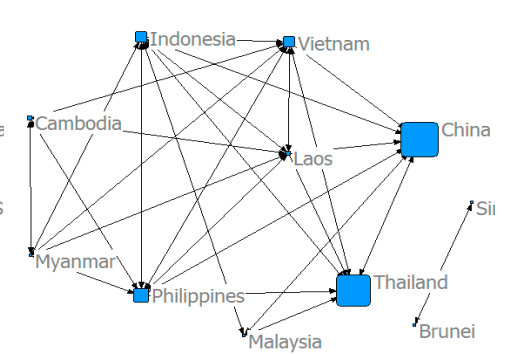

(d) 2012

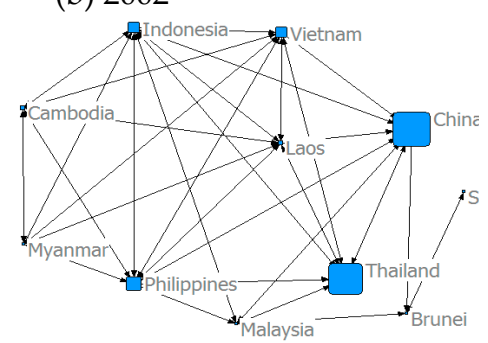

(e) 2017

Figure 1. Tourism cooperation networks on China-ASEAN in 1998, 2002, 2007, 2012 and 2017.

Additionally, this study uses the network density centralization to measure the overall characteristics of tourism cooperation networks of China-ASEAN countries. The results are shown in Figure 2. 


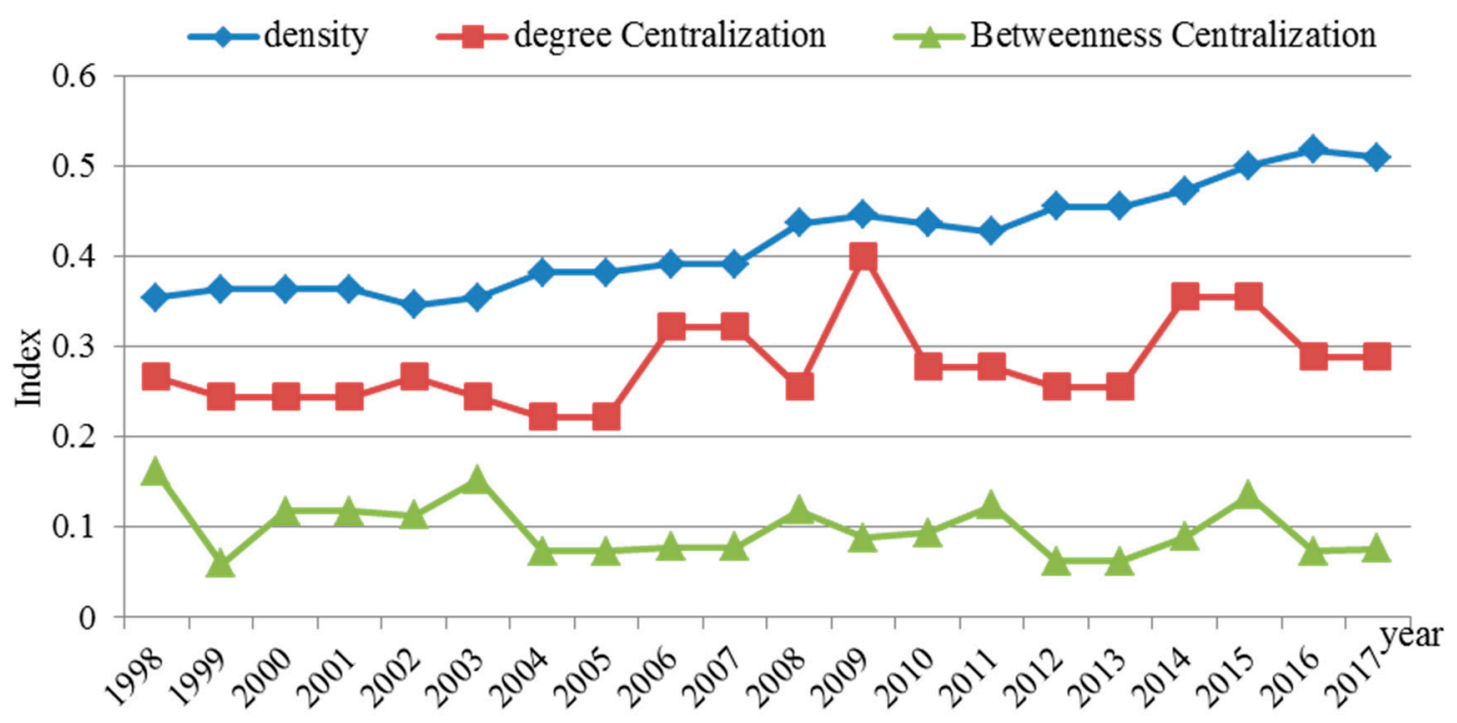

Figure 2. Overall characteristics of the tourism cooperation networks from 1998 to 2017.

Network Density: The density of the tourism cooperation network grew stably from 1998 to 2017, as shown by the density value increases from 0.3545 in 1998 to 0.5091 in 2017 . However, we revealed that there was a temporary decline in 2002, 2010, and 2011. In 2001, In 2001, the 9/11 incident occurred, which resulted in a sharp downturn in the international tourism industry [111] by presenting a decline in tourism cooperation in China-ASEAN countries. The international financial crisis in 2009 has had a huge impact on the world economy, which may have resulted in the decline of tourism cooperation in 2010 and 2011.

Centralization: The degree of centralization of the network has a fluctuating growth trend from 1998 to 2017, but it does not exceed 40\%, indicating that there is not an obvious leader shown in this network. However, the betweenness centralization shows a fluctuating downward trend over the data period. It represents that the role of "intermediary" might not be as important as before. We argue that this essential finding might result from the role of direct cooperation being enhanced among countries, which might weaken the role of "intermediary" in this network.

\subsubsection{Individual Characteristics of the Network}

By analyzing the betweenness and structural hole of the tourism cooperation network, we can derive the change of individual characteristics, including betweenness, effective size, efficiency, and constraints for the cooperation network and the results are shown in Table 1.

Concerning the betweenness, before 2013, the degree of betweenness presents a significant decline, which means that the role of "intermediary" for the China-ASEAN tourism cooperation network was weakened, as revealed by the maximum value decrease from 17.778 (China) in 1998 to 6.44 (Indonesia) in 2013 in Table 1. However, after 2013, the betweenness presents an increase. Furthermore, China acted as the middleman for the entire cooperation network. In 2013, the Belt and Road Initiative (BRI) was proposed by China. China has acted as the initiator and main promoter of the BRI, which is probably the main reason why it has become the intermediary for the China-ASEAN tourism cooperation network.

As for the change of effective size,Table 1 shows that the effective size of the country ranking first has not changed significantly (fluctuating around 3). Thus, we argue that the effective size of the China-ASEAN tourism cooperation network is still relatively small, and the scale of tourism cooperation needs to be further expanded presently. Besides, leading countries of effective size are constantly changing, which means that there are no strong leaders in the network. 
Table 1. Ranking the first country for diverse individual characteristics from 1998 to 2017.

\begin{tabular}{|c|c|c|c|c|c|c|c|c|}
\hline \multirow{2}{*}{ Year } & \multicolumn{2}{|c|}{ Betweenness } & \multicolumn{2}{|c|}{ Effective size } & \multicolumn{2}{|c|}{ Efficiency } & \multicolumn{2}{|c|}{ Constraints } \\
\hline & Country & Value & Country & Value & Country & Value & Country & Value \\
\hline 1998 & China & 17.778 & China & 3.182 & Thailand & 0.778 & China & 0.509 \\
\hline 1999 & Philippines & 10.392 & China/Indonesia & 2.955 & China/Indonesia & 0.563 & China/Indonesia & 0.534 \\
\hline 2000 & Thailand & 15.556 & Indonesia & 2.818 & Thailand & 0.625 & Vietnam & 0.512 \\
\hline 2001 & Thailand & 15.556 & Indonesia & 2.833 & Thailand & 0.625 & Indonesia & 0.519 \\
\hline 2002 & Thailand & 15.556 & Laos & 2.944 & Thailand & 0.625 & Indonesia & 0.532 \\
\hline 2003 & Thailand & 15.556 & Vietnam & 3.167 & Thailand & 0.625 & Vietnam & 0.506 \\
\hline 2004 & China & 12.407 & China & 3.100 & Thailand & 0.563 & Vietnam & 0.518 \\
\hline 2005 & China & 12.407 & China & 3.100 & Thailand & 0.563 & Vietnam & 0.518 \\
\hline 2006 & Indonesia & 10.500 & Indonesia & 3.542 & Indonesia & 0.506 & Indonesia & 0.483 \\
\hline 2007 & Indonesia & 10.500 & Indonesia & 3.542 & Indonesia & 0.506 & Indonesia & 0.483 \\
\hline 2008 & Malaysia & 10.500 & Indonesia & 3.125 & Malaysia & 0.583 & Vietnam & 0.478 \\
\hline 2009 & Indonesia & 12.593 & Philippines & 3.857 & Indonesia & 0.482 & Indonesia & 0.425 \\
\hline 2010 & Indonesia & 7.654 & Philippines & 3.286 & Philippines & 0.469 & Philippines & 0.460 \\
\hline 2011 & Indonesia & 7.654 & Philippines & 3.429 & Philippines & 0.490 & Philippines & 0.456 \\
\hline 2012 & Indonesia & 6.444 & Indonesia & 3.077 & Indonesia & 0.440 & Philippines & 0.467 \\
\hline 2013 & Indonesia & 6.444 & Indonesia & 3.077 & Indonesia & 0.440 & Philippines & 0.467 \\
\hline 2014 & Indonesia & 8.889 & Indonesia & 3.600 & Indonesia & 0.450 & Indonesia & 0.420 \\
\hline 2015 & Malaysia & 35.556 & Indonesia & 3.333 & Malaysia & 0.475 & Indonesia & 0.426 \\
\hline 2016 & China & 22.593 & Philippines & 3.375 & Philippines & 0.422 & Philippines & 0.418 \\
\hline 2017 & China & 22.593 & Indonesia & 3.333 & China & 0.422 & Indonesia & 0.426 \\
\hline
\end{tabular}

Regarding changes inefficiency, we revealed that the country that plays the most powerful role in the network is often changing since Thailand, China, Indonesia, and the Philippines have taken up this role successively. However, we also found that the overall efficiency of the network is decreasing because some countries do not have as powerful an influence on the cooperation networks of these countries as before, implying that cooperation network is moving towards the direction of equality and balance among these countries.

About the change in constraints, we noticed that the degree of constraints for China-ASEAN countries is gradually decreasing, indicating that cooperation liberalization and facilitation are gradually improving. As a result, we suggest that countries with lower constraints such as China, Indonesia, Vietnam, and the Philippines take the initiative to cooperate with other countries.

\subsection{The Formation Mechanism of Tourism Cooperation of China-ASEAN}

By employing the QAP regression approach, we explored whether tourism cooperation network would be affected by these factors including political system difference (PSD), governance difference (GD), income difference (ID), consumption level difference (CLD), security difference (SD), population density difference (PDD), and language difference (LD) for China and ASEAN countries. The results are presented in Table 2.

Table 2 reveals that political system difference has a positive effect on tourism cooperation. In particular, it has significant effects on cooperation, especially in 1999, 2003-2008, and 2011. The difference in the political system will directly lead to many differences in various management systems and social development among countries, which may become one of the attractions for tourists. The positive effect of the difference in the political system does not support Hypothesis 1.

Governance difference negatively impacts tourism cooperation. Specifically, it has significant negative effects on tourism cooperation from 1998 to 2011. After 2011, the significantly negative effects disappeared. With the negative effects, Hypothesis 2 is supported. As an important guarantee for the tourism industry [71,72], the governance capacity affects the performance of tourism to a certain extent. The huge governance difference between the two countries is not conducive to tourism cooperation between the two countries. 
Table 2. Quadratic Assignment Procedure (QAP) regression analysis.

\begin{tabular}{|c|c|c|c|c|c|c|c|c|c|}
\hline Year & PSD & GD & ID & CLD & SD & PDD & LD & $\mathbf{R}^{2}$ & $\operatorname{Adi}-R^{2}$ \\
\hline 1998 & 0.017 & $-0.494^{* * *}$ & $-0.666^{*}$ & 0.345 & 0.057 & 0.150 & -0.019 & 0.408 & 0.374 \\
\hline 1999 & $0.137^{*}$ & $-0.367^{* *}$ & -0.532 & 0.158 & 0.042 & 0.132 & -0.003 & 0.348 & 0.310 \\
\hline 2000 & 0.126 & $-0.436^{* *}$ & $-0.759 * *$ & 0.496 & 0.050 & 0.080 & 0.035 & 0.375 & 0.338 \\
\hline 2001 & 0.071 & $-0.643^{* * *}$ & $-0.814^{* *}$ & 0.648 * & -0.040 & 0.083 & 0.062 & 0.514 & 0.485 \\
\hline 2002 & 0.118 & $-0.549^{* * *}$ & $-0.773 * *$ & $0.505^{*}$ & -0.009 & 0.127 & 0.039 & 0.450 & 0.418 \\
\hline 2003 & $0.137^{*}$ & $-0.589 * * *$ & $-0.827^{* *}$ & $0.631 *$ & 0.071 & 0.062 & 0.047 & 0.494 & 0.465 \\
\hline 2004 & $0.224 * *$ & $-0.568^{* * *}$ & -0.068 & 0.243 & 0.013 & 0.149 & -0.021 & 0.506 & 0.477 \\
\hline 2005 & $0.148^{*}$ & $-0.651^{* * *}$ & $-0.981^{* *}$ & $0.690 *$ & -0.051 & $0.156^{*}$ & 0.074 & 0.597 & 0.574 \\
\hline 2006 & $0.243^{* * *}$ & $-0.598^{* * *}$ & -0.314 & 0.051 & -0.091 & 0.153 & 0.026 & 0.499 & 0.470 \\
\hline 2007 & $0.214^{* *}$ & $-0.460 * *$ & $-0.254 *$ & -0.106 & -0.136 & 0.146 & 0.017 & 0.433 & 0.400 \\
\hline 2008 & $0.196^{* *}$ & $-0.365^{* *}$ & -0.125 & $-0.300 *$ & -0.049 & 0.126 & -0.020 & 0.437 & 0.404 \\
\hline 2009 & 0.110 & $-0.242 *$ & -0.188 & $-0.353 *$ & -0.001 & 0.107 & 0.046 & 0.438 & 0.406 \\
\hline 2010 & 0.110 & $-0.285^{*}$ & $-0.340^{* *}$ & $-0.238^{*}$ & 0.025 & 0.158 & 0.064 & 0.448 & 0.415 \\
\hline 2011 & $0.125 *$ & $-0.295 *$ & -0.223 & $-0.304 *$ & 0.098 & 0.148 & 0.049 & 0.453 & 0.421 \\
\hline 2012 & 0.096 & -0.036 & $-0.340^{* *}$ & $-0.404^{* *}$ & $0.149^{*}$ & 0.113 & 0.042 & 0.478 & 0.447 \\
\hline 2013 & 0.083 & -0.166 & $-0.302 *$ & $-0.345^{* *}$ & 0.117 & 0.136 & 0.052 & 0.483 & 0.453 \\
\hline 2014 & 0.100 & -0.081 & $-0.346^{* *}$ & $-0.426^{* *}$ & 0.095 & 0.149 & 0.060 & 0.516 & 0.488 \\
\hline 2015 & 0.032 & -0.085 & $-0.450^{* *}$ & $-0.301^{* *}$ & $0.167^{*}$ & 0.112 & 0.012 & 0.531 & 0.503 \\
\hline 2016 & 0.040 & -0.162 & $-0.451 * * *$ & $-0.304^{* *}$ & $0.178^{* *}$ & 0.163 & 0.020 & 0.546 & 0.519 \\
\hline 2017 & 0.027 & -0.179 & $-0.386^{* *}$ & $-0.346^{* *}$ & $0.142^{*}$ & $0.155^{*}$ & 0.015 & 0.538 & 0.511 \\
\hline
\end{tabular}

*** Statistically significant at 0.001 level; ${ }^{* *}$ statistically significant at 0.01 level; ${ }^{*}$ statistically significant at 0.05 .

Regarding the income difference factor, we observed that income difference has negative effects on tourism cooperation with a significant negative impact on tourism cooperation in most years (1998, 2000-2003, 2005, 2007, 2010, and 2012-2017). Hypothesis 3 is supported. Income is still a major part restricting the generation of tourism activities.

According to Table 2, the difference in consumption level has a complicated influence on tourism cooperation. The difference in consumption level presents a positive effect on tourism cooperation before 2006, especially having a significantly positive effect in 2001,2002, 2003, and 2005. Additionally, it has a significant negative influence on tourism cooperation after 2008. Based on this complex phenomenon, Hypothesis 4 is not supported.

Regarding the influence of security difference, the positive effects on tourism cooperation were presented in 2012 and 2015-2017, supporting Hypothesis 5. A safe environment is a necessary condition for tourism activities. Tourists tend to choose safe destinations. As a result, security difference moderately promotes tourism cooperation.

Population density difference has a positive effect on tourism cooperation, especially in 2005 and 2017. According to the positive effect, Hypothesis 6 is supported. The difference in population density between the two countries means the difference in the tourism environment, which is also an important thrust for tourism cooperation.

Language difference has a positive effect on tourism cooperation, although these effects are not significant. Therefore, Hypothesis 7 is not supported. The positive effect reveals that language difference is no longer an obstacle for international tourism. In the international tourism environment, language difference represents the cultural difference, which becomes one of the attractions for tourists.

Based on the above analysis, the current study constructed the formation mechanism of tourism cooperation in China-ASEAN countries (Figure 3). We observed that political system difference, security difference, population density difference, and language difference jointly promote tourism cooperation. However, governance difference, income difference, and consumption level difference are obstacles for tourism cooperation presently. 


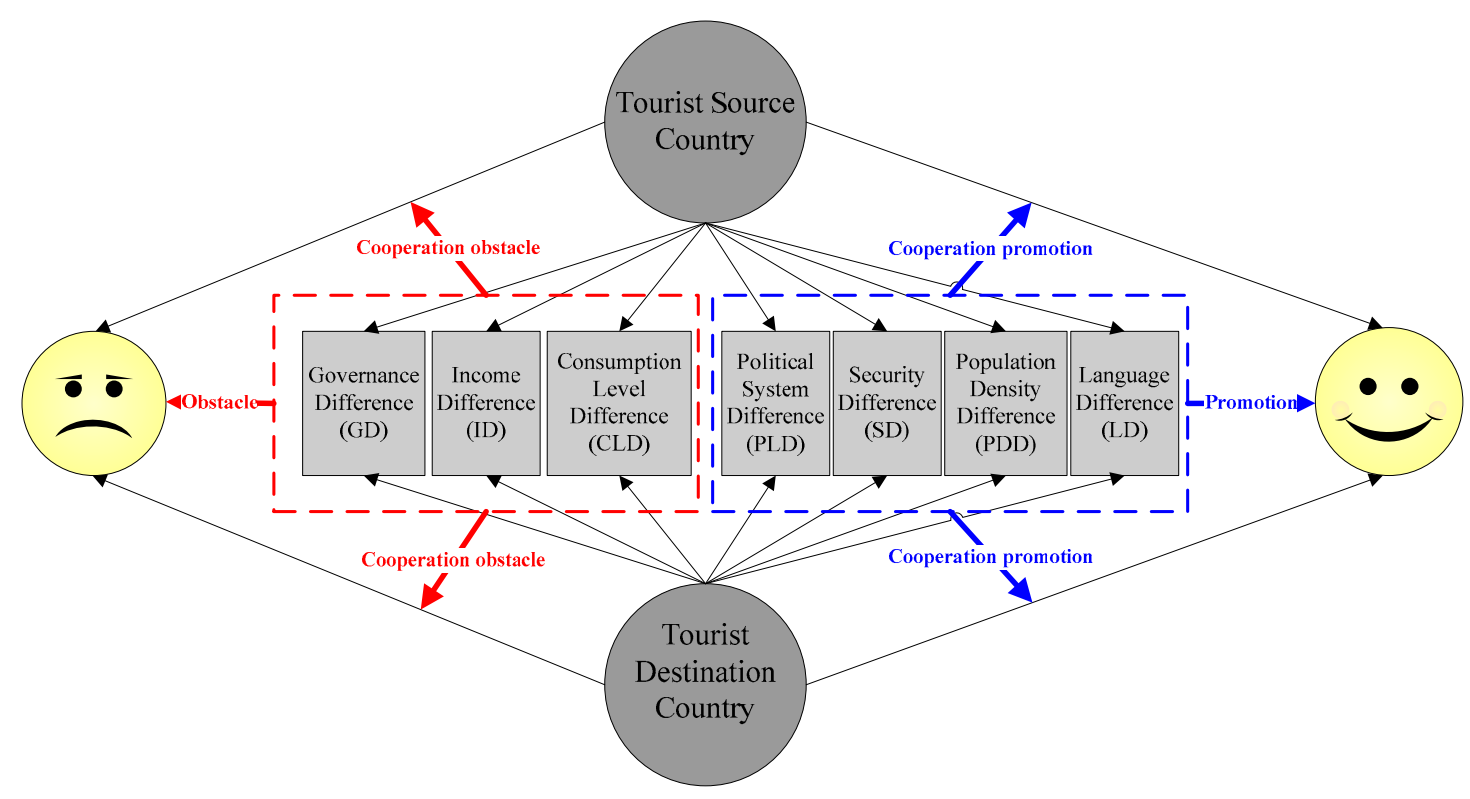

Figure 3. Formation mechanism of China-ASEAN tourism cooperation.

\section{Discussion and Implications}

\subsection{Conclusion}

To summarize, this study measured the tourism cooperation ties of China-ASEAN countries using the modified gravity model, examined the structure of tourism cooperation through the social network analysis method, and identified the factors affecting tourism cooperation networks by employing the QAP analysis method. The results of this study contribute to tourism cooperation with several implications.

On the one hand, this study found that tourism cooperation in China-ASEAN countries has obvious structural characteristics. The scale of tourism cooperation is still small, even though the relationships in tourism cooperation for China-ASEAN are getting closer. The rapid growth of tourism in ASEAN countries can reflect the close relationship in tourism cooperation. Considering the cooperation model, the role of intermediaries has been gradually reduced since the autonomy of the network is gradually strengthening. Direct cooperation becomes a popular cooperation type that can support tourists and improve cooperation effects. As for the cooperation efficiency, the overall efficiency of the network is decreasing due to some countries not having as powerful as an influence on cooperative networks as before.

On the other hand, this study investigated the factors for tourism cooperation by using the QAP analysis. The differences in governance and income have negative effects on tourism cooperation. In detail, before 2011, governance difference has a significantly negative effect on tourism cooperation. Furthermore, the significant negative effect disappeared after 2011. Income difference has a negative effect on tourism cooperation; however, this negative effect is significant only in certain years. However, differences in the political system, security, population density, and language positively affect tourism cooperation. Besides, consumption level difference has a positive effect before 2006 and a negative effect after 2006. In detail, we analyzed and discussed these conclusions separately.

\subsection{Discussion}

Concerning the positive effects, political system difference promotes tourism cooperation. In line with previous studies, this study verified the influence of the political system on tourism development [67-69]. The difference in the political system can directly lead to many differences in various management systems and social development among countries, which may become one of 
the attractions for tourists. For tourists, it is the essence of tourism to seek the environment different from the residential area. Therefore, political system difference becomes one of the determinants for tourists to select a destination. Additionally, increased crime rates are the problem that ASEAN countries currently face concerning tourism [19]. A safe environment has become an important basis for tourists from ASEAN countries to select their destinations. Thus, the security difference positively affects tourism cooperation. Peng et al. [112] stated that population size has a positive effect on tourism demand, which supports the positive effect of population density difference on cooperation. The higher the population density in a region, the higher the arrivals from that region [113]. Thus, tourist flows are more likely to occur. Even though language difference does not have a significant impact on tourism cooperation, we observed the potential positive effect of the language difference. Basala and Klenosky [114] noted tourists prefer to choose countries and destinations that speak the same language, which is more convenient for them. However, language difference not only represents a different official language but also represents deep cultural differences, which positively promotes international tourism activities [115-117]. Therefore, how to explore cultural differences, attract tourists, and promote tourism cooperation has become an important issue of China-ASEAN tourism cooperation.

Regarding the negative effects, governance difference negatively affects tourism cooperation. Governance is regarded as an essential factor for a country to develop tourism [118] because strengthening governance ability has become a prerequisite in terms of promoting tourism development [119]. However, governance difference may cause differences in the government system, lifestyle, and social rules, which may lead to discomfort and inconvenience for tourists from other countries. It is difficult for tourists to visit countries with many differences. Therefore, governance difference negatively affects tourism cooperation. As a supportive factor for tourism activities, the income directly determines whether tourism activities can be realized. As for the international tourism market, tourist flows are affected by economic factors such as price, income, and exchange rate [36,73-76]. It is difficult for tourists from the two countries to visit each other if the income difference of tourists in the two countries is huge. Additionally, most countries may expect to cooperate with countries with strong economies. Therefore, it is reasonable to find that income difference may inhibit tourism cooperation.

This research discussed the complex effects of consumption level difference. First, consumption level difference appears to have a positive impact on tourism cooperation, because the difference in consumption level mainly means the difference in tourism cost. Tourism activities belong to consumption activities, and the cost is an important factor in restricting tourism activities. Differences in consumption levels express differences in travel costs. Consequently, tourists may travel to countries with lower consumption levels, which contributes to tourism cooperation. With the development of tourism and the increase in tourists' income, tourists are more concerned about quality than cost. For tourists, low tourism costs may connote low tourism quality, which would reduce tourism demand [120]. Thus, consumption level difference negatively impacts tourism cooperation presently.

\subsection{Implications}

According to the findings of this study, this paper found that tourism cooperation in China-ASEAN countries can be strengthened from the following aspects.

On the one hand, we need to adjust the structure of cooperation and strengthen cooperation links. First, we need to expand the tourism cooperation size in responding to its small scale. At present, China-ASEAN tourism cooperation needs to be expanded. Therefore, we can promote cooperation in the tourism market, passenger flow, information, culture, and marketing to expand the scale of tourism cooperation. Second, we need to adjust the cooperation model. Direct dialogue and cooperation between governments need to be encouraged, and tourism cooperation between countries should be strengthened through the signing of memoranda and cooperation agreements between governments. Additionally, tourism enterprises of the countries also need to actively cooperate. Enterprises and governments can jointly promote tourism cooperation. Third, cooperation efficiency needs to be 
improved. For the entire network, we need strong leadership to promote the development of the network. To overcome the dilemma, it is important to cultivate the network leaders while improving their network cooperation efficiency. It is encouraged to present the demonstrative and leading role to promote close cooperation between the entire network in China-ASEAN countries.

On the other hand, we need to identify the promotion factors and promote cooperation. We can improve the promoting effect of positive factors such as political system difference and security difference. First, we should reinforce the attractions of political system difference. We can regard a series of differences formed by the regime differences as tourist attractions to induce tourists by developing corresponding tourism products and routes. Second, we must create a safe environment for tourists and strengthen the security of tourists. Third, we should emphasize the role of cultural attractions by using exemplary culture as an important way to attract international tourists. Additionally, we should suppress the negative effects of negative factors. The difference in governance is an important factor hindering tourism cooperation. Therefore, countries should focus on strengthening their governance capacity to create a convenient tourism environment for tourists.

Even though this study revealed the structure of tourism cooperation in China-ASEAN countries and empirically tested the influencing factors of the network, it has certain limitations. First, this study only explored the characteristics of tourism cooperation after the basic formation of ASEAN's ten member countries. However, ASEAN was formally established in 1967. It is of great significance to explore the historical experience and evolution of tourism cooperation among ASEAN countries for adjusting the cooperation structure in the future. Second, additional important driving factors for cooperation networks exist and are worth exploring in the future. It is acknowledged that this study attempted to explore the important impact of the political system on tourism cooperation [121]. Other political influences are issues we leave for future research. It is necessary to consider the direction of tourism cooperation through the direction of tourist flow to reveal cooperation characteristics in future research.

Author Contributions: J.Y. analyzed the data and wrote the original draft. Y.B. designed the research model, analyzed the data, reviewed, and editing the paper. Y.J. collected and analyzed the data. All authors have read and agreed to the published version of the manuscript.

Funding: This research received no external funding.

Conflicts of Interest: The authors declare no conflict of interest.

\section{References}

1. Bornhorst, T.; Ritchie, J.R.B.; Sheehan, L. Determinants of tourism success for DMOs \& destinations: An empirical examination of stakeholders' perspectives. Tour. Manag. 2010, 31, 572-589.

2. Beritelli, P. Cooperation among prominent actors in a tourist destination. Ann. Tour. Res. 2010, 38, 607-629. [CrossRef]

3. Morrison, A.; Lynch, P.; Johns, N. International Tourism Network. Int. J. Contemp. Hosp. Manag. 2004, 16, 197-202. [CrossRef]

4. McSweeney-Feld, M.H.; Discenza, S.; Feis, G.L.D. Strategic Alliances \& Customer Impact: A Case Study of Community Hospitals. J. Bus. Econ. Res. 2010, 8, 13-22.

5. Jesus, C.; Franco, M. Cooperation networks in tourism: A study of hotels and rural tourism establishments in an inland region of Portugal. J. Hosp. Tour. Manag. 2016, 29, 165-175. [CrossRef]

6. Tosun, C.; Timothy, D.J.; Parpairis, A.; Macdonald, D. Cross-Border Cooperation in Tourism Marketing Growth Strategies. J. Travel Tour. Mark. 2005, 18, 5-23. [CrossRef]

7. Baggio, R. Collaboration and cooperation in a tourism destination: A network science approach. Curr. Issues Tour. 2011, 14, 183-189. [CrossRef]

8. Czernek, K. Determinants of Cooperation in a Tourist Region. Ann. Tour. Res. 2013, 40, 83-104. [CrossRef]

9. Yin, J.; Zheng, X.; Li, S. Cooperation Situation and Power Role:Deconstruction of Tourism Cooperation Network of Countries along the Belt and Road Initiative. Econ. Geogr. 2019, 39, 216-224. 
10. Wäsche, H. Interorganizational cooperation in sport tourism: A social network analysis. Sport Manag. Rev. 2015, 18, 542-554. [CrossRef]

11. Makkonen, T.; Hokkanen, T.J.; Morozova, T.; Suharev, M. A social network analysis of cooperation in forest, mining and tourism industries in the Finnish-Russian cross-border region: Connectivity, hubs and robustness. Eurasian Geogr. Econ. 2019, 59, 685-707. [CrossRef]

12. Timur, S.; Getz, D. A network perspective on managing stakeholders for sustainable urban tourism. Int. J. Contemp. Hosp. Manag. 2008, 20, 445-461. [CrossRef]

13. Czernek-Marszałek, K. Cooperation evaluation with the use of network analysis. Ann. Tour. Res. 2018, 72, 126-139. [CrossRef]

14. Studzieniecki, T.; Soares, J.R. International Tourism Cooperation: A Europe Case Study. Holos 2017, 33, 135-158. [CrossRef]

15. Li, W.Y.; Liu, H.Z. The Construction of "One Belt One Road" from the Perspective of Multi-dimension: Space, Economy, Culture and Institution. Int. Econ. Trade Res. 2016, 32, 99-112.

16. Ye, L.; Chen, X. Analysis on Interaction of Tourism Trade between China and ASEAN Countries Based on Evaluation on Tourism Competitiveness. Econ. Geogr. 2013, 33, 177-181.

17. Ariff, M.R.M.; Selvaraju, M.; Tusop, M.E.B.M. Commonalities Inintra-ASEAN Tourism: Harnessing the power of 10. Jati-J. Soutneast Asian Stud. 2005, 10, 91-107.

18. Yousu, A.; Lal, R. The impact of ASEAN on tourism. Int. J. Netw. Parallel Comput. 2013, 2, 38-44.

19. Wakimin, N.F.; Azlinaa, A.A.; Hazman, S. Tourism demand in Asean-5 countries: Evidence from panel data analysis. Manag. Sci. Lett. 2018, 677-690. [CrossRef]

20. Chang, C.-L.; Khamkaew, T.; Tansuchat, R.; McAleer, M. Interdependence of International Tourism Demand and Volatility in Leading ASEAN Destinations. Tour. Econ. 2011, 17, 481-507. [CrossRef]

21. Wannapan, S.; Chaiboonsri, C.; Sriboonchitta, S. Identification of the connection between tourism demand and economic growth in ASEAN-3. Int. J. Trade Glob. Mark. 2018, 11, 12-20. [CrossRef]

22. Yahya, F. Tourism flows between India and Singapore. Int. J. Tour. Res. 2003, 5, 347-367. [CrossRef]

23. Chirathivant, S. ASEAN-India Cooperation in Trade and Tourism: Trends and Prospects. J. Asian Econ. 1996, 7, 743-757. [CrossRef]

24. Wong, E.P.Y.; Mistilis, N.; Dwyer, L. A framework for analyzing intergovernmental collaboration-The case of ASEAN tourism. Tour. Manag. 2011, 32, 367-376. [CrossRef]

25. Timothy, D.J. Supranationalist Alliances and Tourism: Insights from ASEAN and SAARC. Curr. Issues Tour. 2003, 6, 250-266. [CrossRef]

26. Wong, E.P.Y.; Mistilis, N.; Dwyer, L. Understanding ASEAN tourism collaboration - the preconditions and policy framework formulation. Int. J. Tour. Res. 2010, 12, 291-302. [CrossRef]

27. Liu, Y.; Li, Y.; Li, L. A panel data-based analysis of factors influencing market demand for Chinese outbound tourism. Asia Pac. J. Tour. Res. 2018, 23, 667-676. [CrossRef]

28. Wu, M.-Y.; Wall, G.; Tong, Y. Research on China's Inbound Tourism: A Comparative Review. J. China Tour. Res. 2019, 15, 320-339. [CrossRef]

29. Cheng, J.Y.-s. The ASEAN-China Free Trade Area: Genesis and implications. Aust. J. Int. Aff. 2010, 58, 257-277. [CrossRef]

30. Roberts, B. A Gravity Study of the Proposed China-Asean Free Trade Area. Int. Trade J. 2004, 18, 335-353. [CrossRef]

31. Arase, D. Non-Traditional Security in hina-ASEAN Cooperation. Asian Surv. 2010, 50, 808-833. [CrossRef]

32. Cheng, J.Y.-s. China-ASEAN Economic Co-operation and the Role of Provinces. J. Contemp. Asia 2013, 43, 314-337. [CrossRef]

33. Zeng, Q.; Adams, J.; Gibbs, A. Are China and the ASEAN ready for a Bologna Process?-Factors affecting the establishment of the China-ASEAN higher education area. Educ. Rev. 2013, 65, 321-341. [CrossRef]

34. Arroll, J. Tourism cooperation in the Asia-Pacific region. Tour. Manag. 1993, 14, 390-392. [CrossRef]

35. Fagence, M. Regional tourism cooperation. Tour. Res. 1996, 7, 177-196. [CrossRef]

36. Tan, A.Y.F.; McCahon, C.; Miller, J. Modeling Tourist Flows to Indonesia and Malaysia. J. Travel Tour. Mark. 2002, 13, 61-82. [CrossRef]

37. Czernek-Marszałek, K. Applying mixed methods in social network research: The case of cooperation in a Polish tourist destination. J. Destin. Mark. Manag. 2019, 11, 40-52. [CrossRef] 
38. Fu, X.-M.; Chen, H.-X.; Xue, Z.-K. Construction of the Belt and Road Trade Cooperation Network from the Multi-Distances Perspective. Sustainability 2018, 10, 1439. [CrossRef]

39. Park, D.; Lee, G.; Kim, W.G.; Kim, T.T. Social Network Analysis as a Valuable Tool for Understanding Tourists' Multi-Attraction Travel Behavioral Intention to Revisit and Recommend. Sustainability 2019, 11, 2497. [CrossRef]

40. Leung, X.Y.; Wang, F.; Wu, B.; Bai, B.; Stahura, K.A.; Xie, Z. A social network analysis of overseas tourist movement patterns in Beijing: The impact of the Olympic Games. Int. J. Tour. Res. 2012, 14, 469-484. [CrossRef]

41. Lew, A.; McKercher, B. Modeling tourist movements: A local destination analysis. Ann. Tour. Res. 2006, 33, 403-423. [CrossRef]

42. Long, J. Regional tourism cooperation in triangle zone of liaoning province. Chin. Geogr. Sci. 2005, 15, $261-367$. [CrossRef]

43. Jamal, T.B.; Getz, D. Collaboration theory and community tourism planning. Ann. Tour. Res. 1995, 22, $186-204$. [CrossRef]

44. Bramwell, B.; Angela, S. Collaborations in municipal tourism policy making. Ann. Tour. Res. 2001, 26, 392-415. [CrossRef]

45. Cetinski, V.; Weber, S. Tourism marketing in CEI countries: Possibilities for cooperation in health tourism. Tour. Hosp. Manag. 1996, 2, 45-56.

46. Teye, V.B. Prospects for regional tourism cooperation in Africa. Tour. Manag. 1988, 9, 221-234. [CrossRef]

47. Elliott, J. Tourism Politics and Public Sector Management; Routledge: London, UK, 1997.

48. Pestana, M.H.; Sánchez, A.V.; Moutinho, L. The network science approach in determining the intellectual structure, emerging trends and future research opportunities-An application to senior tourism research. Tour. Manag. Perspect. 2019, 31, 370-382. [CrossRef]

49. Baggio, R. Tourism destinations: A universality conjecture based on network science. Ann. Tour. Res. 2020, 82, 102929. [CrossRef]

50. Quatman, C.; Chelladurai, P. Social Network Theory and Analysis: A Complementary Lens for Inquiry. J. Sport Manag. 2008, 22, 338-360. [CrossRef]

51. Chung, M.G.; Herzberger, A.; Frank, K.A.; Liu, J. International Tourism Dynamics in a Globalized World: A Social Network Analysis Approach. J. Travel Res. 2020, 59, 387-403. [CrossRef]

52. Provenzano, D.; Baggio, R. A complex network analysis of inbound tourism in Sicily. Int. J. Tour. Res. 2019. [CrossRef]

53. Yi, J.; Ryan, C.; Wang, D. China's Village Tourism Committees: A Social Network Analysis. J. Travel Res. 2020. [CrossRef]

54. Raisi, H.; Baggio, R.; Barratt-Pugh, L.; Willson, G. Hyperlink Network Analysis of a Tourism Destination. J. Travel Res. 2017, 57,671-686. [CrossRef]

55. Tran, M.T.T.; Jeeva, A.S.; Pourabedin, Z. Social network analysis in tourism services distribution channels. Tour. Manag. Prospect. 2016, 16, 59-67. [CrossRef]

56. Amblard, F.; Kelman, I.; Luthe, T.; Wyss, R.; Tørnblad, S.H.; Evers, Y.; Curran, M.M.; Williams, R.J.; Berlow, E.L. Social Network Analysis and Qualitative Interviews for Assessing Geographic Characteristics of Tourism Business Networks. PLOS ONE 2016, 11, e0156028.

57. Miguéns, J.I.L.; Mendes, J.F.F. Travel and tourism: Into a complex network. Phys. A Stat. Mech. Appl. 2008, 387, 2963-2971. [CrossRef]

58. Liu, Y.; Li, Y.; Parkpian, P. Inbound tourism in Thailand: Market form and scale differentiation in ASEAN source countries. Tour. Manag. 2018, 64, 22-36. [CrossRef]

59. Koh, S.G.M.; Kwok, A.O.J. ASEAN beyond talk shop: A rejoinder to regional tourism. Curr. Issues Tour. 2016, 21, 1085-1090. [CrossRef]

60. Wong, E.P.Y.; Mistilis, N.; Dwyer, L. A model of Asean collaboration in tourism. Ann. Tour. Res. 2011, 38, 882-899. [CrossRef]

61. Novelli, M.; Klatte, N.; Dolezal, C. The ASEAN Community-based Tourism Standards: Looking Beyond Certification. Tour. Plan. Dev. 2016, 14, 260-281. [CrossRef]

62. Isaac, R.K.; Çakmak, E. Understanding visitor's motivation at sites of death and disaster: The case of former transit camp Westerbork, the Netherlands. Curr. Issues Tour. 2013, 17, 164-179. [CrossRef] 
63. Cothrana, D.; Cothran, C.C. Promise or political risk for Mexican tourism. Ann. Tour. Res. 1998, 25, 477-497. [CrossRef]

64. Causevic, S.; Lynch, P. Political (in)stability and its influence on tourism development. Tour. Manag. 2013, 34, 145-157. [CrossRef]

65. Poirier, R.A. Political risk analysis and tourism. Ann. Tour. Res. 1997, 24, 675-686. [CrossRef]

66. Matthews, H.G.; Richter, L.K. Political science and tourism. Ann. Tour. Res. 1991, 18, 120-135. [CrossRef]

67. Ingram, H.; Ingram, H.; Tabari, S.; Watthanakhomprathip, W. The impact of political instability on tourism: Case of Thailand. Worldw. Hosp. Tour. Themes 2013, 5, 92-103. [CrossRef]

68. Henderson, J.C. The Politics of Tourism in Myanmar. Curr. Issues Tour. 2003, 6, 97-118. [CrossRef]

69. Elliot, J. Politics, power, and tourism in Thailand. Ann. Tour. Res. 1983, 10, 377-393. [CrossRef]

70. Hall, C.M. A typology of governance and its implications for tourism policy analysis. J. Sustain. Tour. 2011, 19, 437-457. [CrossRef]

71. Ndivo, R.M.; Okech, R.N. Tourism Governance in Transition Period: Restructuring Kenya's Tourism Administration from Centralized to Devolved System. Tour. Plan. Dev. 2019, 17, 166-186. [CrossRef]

72. Dos Anjos, F.A.; Kennell, J. Tourism, Governance and Sustainable Development. Sustainability 2019, $11,4257$. [CrossRef]

73. Crouch, G.I. The Study of International Tourism Demand: A Review of Findings. J. Travel Res. 1994, 33, 12-23. [CrossRef]

74. Hiemstra, S.; Wong, K.K.F. Factors Affecting Demand for Tourism in Hong Kong. J. Travel Tour. Mark. 2002, 13, 41-60. [CrossRef]

75. White, K.J. An international travel Demand model US Travel to Western Europe. Ann. Tour. Res. 1985, 12, 529-545. [CrossRef]

76. Law, R. The impact of the Asian financial crisis on Japanese demand for travel to Hong Kong: A study of various forecasting techniques. J. Travel Tour. Mark. 2001, 10, 47-65. [CrossRef]

77. Zhang, C.; Weng, S.; Bao, J. The changes in the geographical patterns of China's tourism in 1978-2018: Characteristics and underlying factors. J. Geogr. Sci. 2020, 30, 487-507. [CrossRef]

78. Zimmerhackel, J.S.; Rogers, A.A.; Meekan, M.G.; Ali, K.; Pannell, D.J.; Kragt, M.E. How shark conservation in the Maldives affects demand for dive tourism. Tour. Manag. 2018, 69, 263-271. [CrossRef]

79. Simpson, J.J.; Simpson, P.M.; Cruz-Milán, O. Attitude towards immigrants and security: Effects on destination-loyal tourists. Tour. Manag. 2016, 57, 373-386. [CrossRef]

80. Anser, M.K.; Yousaf, Z.; Awan, U.; Nassani, A.A.; Qazi Abro, M.M.; Zaman, K. Identifying the Carbon Emissions Damage to International Tourism: Turn a Blind Eye. Sustainability 2020, 12, 1937. [CrossRef]

81. Currie, C.; Falconer, P. Maintaining sustainable island destinations in Scotland: The role of the transport-tourism relationship. J. Destin. Mark. Manag. 2014, 3, 162-172. [CrossRef]

82. Gu, Q.; Qiu, H.; King, B.E.M.; Huang, S. Understanding the wine tourism experience: The roles of facilitators, constraints, and involvement. J. Vacat. Mark. 2019, 26, 211-229. [CrossRef]

83. Katz, N.; Lazer, D.; Arrow, H.; Contractor, N. Network Theory and Small Groups. Small Group Res. 2004, 35, 307-332. [CrossRef]

84. Tinbergen, J. An Analysis of World Trade Flows in Shaping the World Economy; The Twentieth Century Fund: New York, NY, USA, 1962.

85. Pöyhönen, P. A Tentative Model for the Volume of Trade between Countries. Weltwirtschaftliches Arch. 1963, 90, 93-100.

86. Morley, C.; Rosselló, J.; Santana-Gallego, M. Gravity models for tourism demand: Theory and use. Ann. Tour. Res. 2014, 48, 1-10. [CrossRef]

87. Stoll, T.; Müller, F.; Baumann, M. When cooperation is needed: The effect of spatial and time distance and criticality on willingness to cooperate. Cogn. Technol. Work 2018, 21, 21-31. [CrossRef]

88. Qiang, M.; Shen, M.; Xie, H. Cultural diffusion and international inbound tourism: Evidence from China. Tour. Econ. 2018, 25, 884-903. [CrossRef]

89. Hanafiah, M.H.M.; Harun, M.F.M. Tourism demand in Malaysia: A cross-sectional pool time-series analysis. Int. J. Trade Econ. Financ. 2010, 1, 80-83.

90. Bell, M. The Spatial Distribution of Second Homes: A Modified Gravity Model. J. Leis. Res. 1977, 9, $225-233$. [CrossRef] 
91. Timothy, D.J.; Kim, S. Understanding the tourism relationships between South Korea and China: A review of influential factors. Curr. Issues Tour. 2015, 18, 413-432. [CrossRef]

92. Tian-Cole, S.H.U.; Cromption, J. A conceptualization of the relationships between service quality and visitor satisfaction, and their links to destination selection. Leis. Stud. 2003, 22, 65-80. [CrossRef]

93. Jeon, S.M.; Magnini, V.P.; Kim, I.; Hyun, S.S. Causal relationships between table game players' perceptions of service quality, perceived winning, and game spending: Moderating effects of demographic factors. Int. J. Contemp. Hosp. Manag. 2013, 25, 922-944. [CrossRef]

94. Nam, M.; Kim, I.; Hwang, J. Can local people help enhance tourists' destination loyalty? A relational perspective. J. Travel Tour. Mark. 2016, 33, 702-716. [CrossRef]

95. Yin, J.; Liu, Y.; Yang, D.; Zheng, X. Study on Tourism Openness of European Countries along the BRI. Econ. Geogr. 2017, 37, 190-197.

96. Scott, J. Social network analysis. Sociology 1988, 22, 109-127. [CrossRef]

97. Wasserman, S.; Faust, K. Social Network Analysis; Cambridge University Press: New York, NY, USA, 1994.

98. Shih, H.-Y. Network characteristics of drive tourism destinations: An application of network analysis in tourism. Tour. Manag. 2006, 27, 1029-1039. [CrossRef]

99. Racherla, P.; Hu, C. A social network perspective of tourism research collaborations. Ann. Tour. Res. 2010, 37, 1012-1034. [CrossRef]

100. Luo, Q.; Zhong, D. Using social network analysis to explain communication characteristics of travel-related electronic word-of-mouth on social networking sites. Tour. Manag. 2015, 46, 274-282. [CrossRef]

101. Buffa, F.; Beritelli, P.; Martini, U. Project networks and the reputation network in a community destination: Proof of the missing link. J. Destin. Mark. Manag. 2019, 11, 251-259. [CrossRef]

102. Liu, B.; Huang, S.; Fu, H. An application of network analysis on tourist attractions: The case of Xinjiang, China. Tour. Manag. 2017, 58, 132-141. [CrossRef]

103. Kim, H.; Chung, J.-K.; Lee, M.-H. Social Network Analysis of the Jangwi Urban Regeneration Community. Sustainability 2019, 11, 4185. [CrossRef]

104. Pan, F.; Lia, Z.; Ge, Y. Analysis of China's surrounding geoenvironment from the perspective of economy and trade-based on social network analysis method. Geogr. Res. 2015, 34, 775-786.

105. Burt, R.S. Secondhand Brokerage: Evidence on the Importance of Local Structure for Managers, Bankers, and Analysts. Acad. Manag. J. 2007, 50, 19-148. [CrossRef]

106. He, Q.; Cao, X. Pattern and Influencing Factors of Foreign Direct Investment Networks between Countries along the "Belt and Road" Regions. Sustainability 2019, 11, 4724. [CrossRef]

107. Krackhardt, D. Predicting with networks: Nonparametric multiple regression analysis of dyadic data. Soc. Netw. 1988, 10, 359-381. [CrossRef]

108. Kaufmann, D.; Kraay, A.; Mastruzzi, M. The Worldwide Governance Indicators: Methodology and Analytical Issues (World Bank Policy Research Working Paper No. 5430); The World Bank: Washington, DC, USA, 2010.

109. Sebudubudu, D.; Makepe, P.M.; Montsi, K.; Bodilenyane, K. Governance of Land and Natural Resource for Sustainable Development in Botswana: Possible Lessons for the Agricultural and Tourism Sectors. Int. J. Afr. Dev. 2014, 2, 81-100.

110. Low, S.-W.; Kew, S.-R.; Tee, L.-T. International Evidence on the Link between Quality of Governance and Stock Market Performance. Glob. Econ. Rev. 2011, 40, 361-384. [CrossRef]

111. Meng, X.; Siriwardana, M.; Dollery, B.; Mounter, S. The Impact of the 2008 World Financial Crisis on Tourism and the Singapore Economy and Policy Responses:A CGE Analysis. Int. J. Trade Econ. Financ. 2010, 1, 46-53.

112. Katelieva, M.; Muhar, A.; Penker, M. Nature-related knowledge as intangible cultural heritage: Safeguarding and tourism utilisation in Austria. J. Tour. Cult. Chang. 2019, 1-17. [CrossRef]

113. Peng, B.; Song, H.; Crouch, G.I. A meta-analysis of international tourism demand forecasting and implications for practice. Tour. Manag. 2014, 45, 181-193. [CrossRef]

114. Massidda, C.; Etzo, I. The determinants of Italian domestic tourism: A panel data analysis. Tour. Manag. 2012, 33, 603-610. [CrossRef]

115. Basala, S.L.; Klenosky, D.B. Travel-Style Preferences for Visiting a Novel Destination: A Conjoint Investigation across the Novelty-Familiarity Continuum. J. Travel Res. 2001, 40, 172-182. [CrossRef]

116. Lien, D.; Yao, F.; Zhang, F. Confucius Institute's effects on international travel to China: Do cultural difference or institutional quality matter? Appl. Econ. 2016, 49, 3669-3683. [CrossRef] 
117. Okafor, L.E.; Khalid, U.; Then, T. Common unofficial language, development and international tourism. Tour. Manag. 2018, 67, 127-138. [CrossRef]

118. Yu, J.Y.; Ko, T.G. A cross-cultural study of perceptions of medical tourism among Chinese, Japanese and Korean tourists in Korea. Tour. Manag. 2012, 33, 80-88. [CrossRef]

119. Mihalič, T.; Šegota, T.; Cvelbar, L.K.; Kuščer, K. The influence of the political environment and destination governance on sustainable tourism development: A study of Bled, Slovenia. J. Sustain. Tour. 2016, 24, 1489-1505. [CrossRef]

120. Ballesteros, J.G.T.; Hernández, M.H. Promoting tourism through the EU LEADER programme: Understanding Local Action Group governance. Eur. Plan. Stud. 2018, 27, 396-414. [CrossRef]

121. Schneider, C.J. The Domestic Politics of International Cooperation. In Oxford Research Encyclopedia of Politics; Oxford University Press: Oxford, UK, 2018.

C 2020 by the authors. Licensee MDPI, Basel, Switzerland. This article is an open access article distributed under the terms and conditions of the Creative Commons Attribution (CC BY) license (http://creativecommons.org/licenses/by/4.0/). 